\title{
THE INFLUENCE OF TOURIST INFRASTRUCTURE ON THE MOUNTAIN LANDSCAPE. TOWARDS A TOURIST LANDSCAPE. CASE STUDY OF THE SILESIAN BESKID
}

\author{
Anna Żemła-Siesicka ${ }^{1}$
}

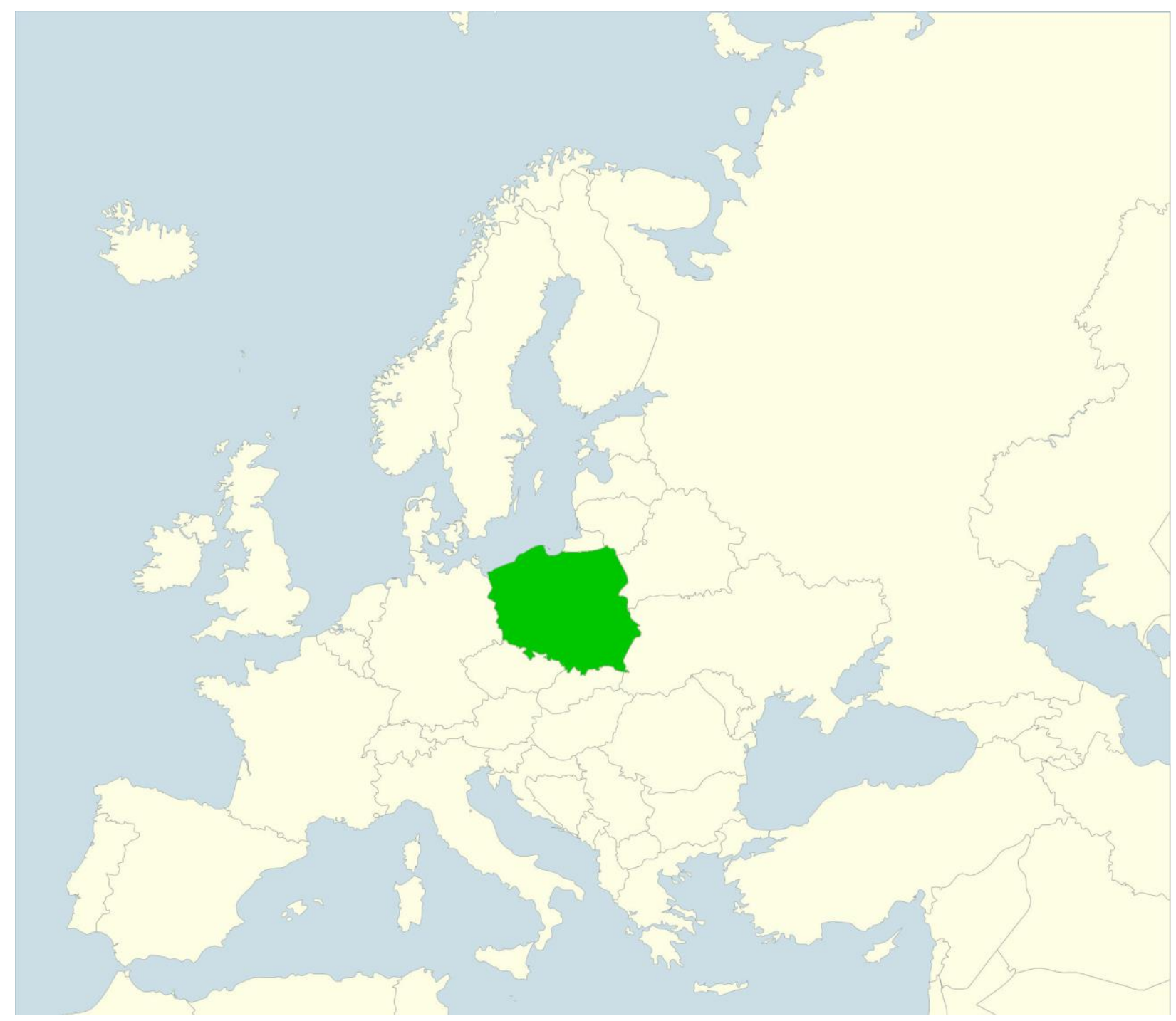

1 dr inż. arch. (PhD) Anna Żemła-Siesicka, University of Silesia, Faculty of Natural Sciences, Institute of Earth Sciences, Będzińska str. 60, 41-200 Sosnowiec, e-mail: anna.zemla-siesicka@us.edu.pl, ORCID: 0000-0003-16778119 
Abstract: The dynamic development of tourist infrastructure can damage the value of a landscape. Thus, the identification of the impact of tourist infrastructure on landscape is an important issue in the context of the limitation of further degradation of landscape. The purpose of this article is to assess the influence of tourist facilities in the mountain landscape of the Silesian Beskids in terms of both spatial and physiognomic aspects. The impact is assessed by using an index of landscape load with tourist infrastructure (landscape load index - LLI) developed by author. The index is based on calculation of the saturation of landscape with cubature, area and linear elements of tourist infrastructure corrected by a coefficient describing the degree of their impact on the landscape. The results indicate the spatial diversity of the landscape load and thus of the transformation of a landscape towards a tourist one. The presented method has an application value in the forecasting and programming of the tourist infrastructure with respect to landscape values.

Keywords: landscape load index, Silesian Beskids, tourist landscape, tourist facilities

\section{Introduction}

The relationship between tourism and landscape has already been the subject of much research (i.e. Andrejczuk, 2010; Gkoltsiou \& Terkenli, 2008; Gormsen, 1997; Gunn, 1979; Jansen-Verbeke \& McKercher, 2013; Myga-Piątek, 2006, 2016; Myga-Piątek \& Jankowski, 2009; Nita, Myga-Piątek \& Absalon, 2015; Terkenli, 2002). In the 1970s, the term 'tourist landscape' was formed (Skowronek, Tucki \& Huijbens, 2018). The understanding of this term is not unanimously agreed upon. Some authors consider it to be an environment of tourism development (Gunn, 1978; Richling, 2010), while others highlight the predominating function (Lozato-Giotart, 1993; Kowalczyk, Derek, 2010) and the physiognomic character determined by the material elements of the tourist infrastructure (Terkenli, 2002; Włodarczyk, 2011; MygaPiątek, 2012). According to Gkoltsiou \& Terkenli (2012), tourist landscapes consist of attributes (symbolic, morphological and functional) and elements, both natural and human-made. Humanmade elements are composed of tourist infrastructure, basic infrastructure and tourist attractions. These anthropogenic elements cause spatial transformations in landscape. The dynamic development of tourist facilities can damage the material, physiognomic and symbolic values of landscape. The spatial arrangement of tourist infrastructure, the most visually apparent formal aspect of tourism development in the landscape, is the subject of lots of research on tourist landscape (Gkoltsiou \& Terkenli, 2012). This article, being based on tourist infrastructure, describes the spatial aspects of the transformation of mountainous, mostly rural and natural landscapes which have been put under pressure from tourism for decades. In many areas, such landscapes have transformed into tourist landscapes (Prince, 2019), leading to the regional identity vanishing and many European regions becoming homogeneous. Identification of the influence of tourist infrastructure on the landscape, and a limitation of any further degradation, is an important issue in terms of rural landscape management.

The problem of maintaining the value of a landscape is particularly important in mountainous areas intensively developed by tourism, as in the case of the Silesian Beskids (Carpathian Mountains, Poland). Striving to preserve the landscape in such areas is an important activity, not only for aesthetic reasons, but also for economic ones. A decrease in the quality of the landscape ultimately results in a decrease in its tourism value and consequently in the number of visitors (Butler, 1996; Briassoulis, 2002). So, the development of tourist infrastructure should respect the landscape value. While programming the development, the existing infrastructure and its impact to the landscape has to be considered. This article presents research in the spatial, physiognomic sphere and attempts to answer the question: how can the influence of tourist infrastructure on landscape physiognomy be estimated?

The intensity and the impact of tourism development is often measured by indicators methods. 
The measures presented in the literature can be divided into two main groups. The first includes indicators measuring the phenomenon of tourism in relation to tourist traffic (i.e. Baretje \& Defert, 1972; Szromek, 2012; Hendel, 2016), the second trend measures the influence of tourism on the environment (ecological indicators), including the landscape (i.e. BaranowskaJanota \& Kozłowski, 1984; Buckly, 2003; Gkoltsiou \& Terkenli, 2008). But no index has been developed so far describing the impact of tourist facilities on the landscape in a qualitative and quantitative manner.

This article closes the research gap in the spatial analyses of tourist infrastructure by proposing an objective method of the assessment of distribution and spatial impact of tourist facilities. The purpose of this article is to assess the influence of tourist facilities. by using the index of landscape load with tourist infrastructure (landscape load index - LLI) developed by the author. The study presents a case of mountain landscape of the Silesian Beskid Mountains. It investigates the existing tourist infrastructure in landscape (spatial) aspects in the geographic field and the planning scale. The results of the original research are presented based on several innovative assumptions. First, the spatial distribution of tourist facilities in the studied mountain area was connected to the landscape's background, which is the river basins which have created its natural "cellular structure". Second, it was assumed that changes in the character of a landscape are caused by all kinds of tourist facilities, not only accommodation and catering elements (which are most often analysed), but also by the supporting infrastructure, such as tourist trails, sports elements and ski slopes. All these elements cause the reduction of natural and typical rural areas in horizontal and vertical terms -tourist elements gradually become the most numerous and visible in the landscape. This article focuses on the spatial context that can be objectively measured and omits subjective aesthetic aspects, such as materials or the style of buildings. The important part of the research is the tourist infrastructure classification based on spatial division, in which tourist elements are distinguished and parameterized in terms of their morphological (shape) and morphometric (dimension) properties. Third, based on the density of elements and the scale of their impact on the landscape, an index of landscape load with tourist infrastructure (landscape load index - LLI) was developed and applied. The results indicate the spatial diversity of the influence of tourist elements and thus of the transformation of natural and rural landscapes into a tourist one. The results have also the application significance as the landscape load should be the basis for determining further development of the tourist infrastructure.

\section{Influence of tourist infrastructure elements on the landscape - literature review}

Landscape and its scenic beauty is a fundamental aspect of tourist destinations (Prince, 2019). This value is often destroyed by the location of tourist infrastructure, especially related to mass tourism. The negative effects of tourist investment are set out (within others hazards) in the Polish landscape audit (Solon et al., 2015), and yet are present in all European countries. In the spatial and physiognomic context of tourist development, these effects are (among others) a threatening of the identity of landscape through its glocalisation; making valuable landscapes more attractive by the location of tourist attractions; covering authentic valuable historical, physiognomic, natural and architectural values with random, unaesthetic (often kitschy) buildings and infrastructure; transposition of buildings with architecture and neovernakular style beyond the landscape context (to another region). All these hazards, with the addition of major investments, such as hotel parking lots or cable-cars, and also small ones, such as billboards or teasing slogans, lead to changes in land use and physiognomy, urbanisation processes and, in effect, to a reduction in natural and rural areas, spatial chaos and the homogenisation of landscapes through a loss of local identity.

Urbanisation is a frequent process in villages which are attractive for tourism. Transformation of the land use and land cover by the reduction of forests and agricultural areas is proven by studies carried out both in the mountains (Boori, Voženílek \& Choudhary, 2015) and in coastal areas (Atik, Altan \& Artar, 2010). Changes in the spatial layout of villages could be caused by a significant increase in the number of new houses (,second homes”) and the development of 
many small tourist accommodations and restaurants. Such processes have been recorded in many Polish Carpathian villages (Mika \& Faracik, 2008). Another case is the one of great resorts emerging in traditional countryside areas. In the mountains, large ski resorts are an important factor for changes in land use and processes of urbanisation (e.g. Donovaly, Čuka, Gregorová, 2011). In coastal areas, seaside tourism development tends to create holiday resorts and, due to the location of new apartments and large hotels, destroys the coastal line (Durydiwka,2014). Many coastal regions in Portugal, Italy, Greece, and particularly in Spain, have this problem. (Atik, Altan, \& Artar, 2010; Sanagustín Fons et al., 2011; Gkoltsiou, Terkenli \& Koukoulas, 2013).

The urbanisation of rural areas is also a factor leading to the homogenisation of landscape resulting in the loss of place identity (Terkenli, 2002). Another example of homogenisation can be seen in architecture. For example, hotel chains most often raised in a modern style, lose their local uniqueness and authenticity ( $Y u$ et al., 2012). On the other hand, regional architecture is transposed to places without context, like mountain-style restaurants located all over Poland, including areas along highways deprived of regional features (Myga-Piątek, 2016).

Another hazard is spatial chaos, which is a result of insufficient investment planning supervision (Kapera, 2010; Meyer, 2011). In areas with mass tourism, the physiognomy of landscape is often disturbed by the presence of billboards, diversity of forms, styles and colours of architecture, and the chaotic location of buildings and parking lots.

There are also positive aspects of the influence of tourism on landscape. As scenic beauty is one of the factors of tourist decisions, tourism provides a positive impulse to restore and preserve a natural and cultural landscape. Some of the villages that have preserved their historic rural character are taking the benefits of the landscape. In Poland, this is mainly the case in eastern areas, e.g. Open Shutters Land in Podlasie (Durydiwka, 2016). Other villages have been under the influence of mass tourism for many years and either became towns (like Wisła in the Silesian Beskids), or are still villages but with rather an urban physiognomy (such as Brenna in the Silesian Beskids).

The impact of tourism on landscape can be estimated by indicator methods, which is an objective measure of geographic phenomena. The indicators developed so far cover various needs related to tourism, its relation with environment and also tourist landscape. In tourism research, indexes are used mostly for an estimation of tourism traffic, such as the Schneider index, or for measuring the level of tourism development, but focused mostly on the accommodation infrastructure, such as Baretje-Defert, Charvat or the accommodation density index (Baretje \& Defert, 1972; Szromek, 2012; Hendel, 2016). Among many indicators describing the impact on the environment, it is worth mentioning an index applied by Mika (2004) in the Beskid Mountains. The index of tourism development pressure on the environment includes a wider range of elements of tourism infrastructure, such as "second homes" or ski slopes.

There is also a significant group of ecological indicators describing the influence of tourism on the environment. They indicate changes in the natural environment caused by various types of tourist activities (Bodoque et al., 2017; Buckly, 2004; Buckley \& Pannell, 1990; Rixen \& Rolando, 2013; Tesler \& Clark, 2016). The most important and common indicator is the one concerning carrying capacity. This index determines the maximum number of people that may visit a tourist destination at the same time, without causing destruction of the physical, economic, sociocultural environment and an unacceptable decrease in the quality of visitors' satisfaction. Carrying capacity (or natural capacity) is the basic measure used in tourism development planning, especially for preserved areas (Baranowska-Janota \& Kozłowski, 1984; Kostopoulou \& Kyritsis, 2006; Manning, 2002; Sayan \& Atik, 2011), but does not consider existing changes in the natural environment or the landscape caused by tourist facilities.

Visual impact most often focuses on the influence of a particular investment. These are an analysis of the visibility range and an aesthetic evaluation of the object itself and its impact on the environment, or an area assessment in terms of the possibility of accepting new facilities, such as visual absorption capacity (Amir \& Gidalizon, 1990; Krajewski \& Mastalska-Cetera, 2014; Ozimek et al., 2010; Rygiel, 2007), visual absorption capability (Anderson et al., 1976) or 
visual impact assessment (i.e. Hernández, García \& Ayuga, 2004; Giedych, 2016). The assessment of transformation processes, such as changes in rural and natural areas, is usually focused on counting the percentage of land use change caused by tourism development, as shown in research carried out on Jesenıky Mountains (Boori, Voženílek \& Choudhary, 2015). By contrast, the density of tourist facilities proposed for Beskid Mountains (Żemła-Siesicka, 2014) is based on the share of land occupied by tourism elements (including all types of infrastructure: accommodation, gastronomy, trails, ski slopes and others).

An important piece of research on tourist landscape transformation estimated by indicators was presented by Gkoltsiou and Terkenli (2008) for the seashore of Kos Island. The interpretation of landscape change caused by tourism was described by five indicators: percentages of land use, density of human-made or built elements, spatial distribution of built elements in the tourist landscape, transportation network development and connectivity and degree of visibility towards the seashore. As the authors noticed, the presented "set of indicators may be a subset of a larger group of indicators describing structural and functional changes in tourist landscapes" (Gkoltsiou and Terkenli, 2008, p. 8).

In the context of research performed on a geographical scale concerning the influence of diverse elements on landscape, it is worth mentioning the landscape load index developed for mines (Csüllög, et al., 2017). This research shows the impact of mining activity on the landscape within adopted landscape units.

Despite numerous measures being described in the literature, there is a clear lack of indicators referring to landscape load with tourist facilities. The existing indicators related to tourism development refer to tourist traffic or accommodation only (and they mostly focus on the number of beds, which cannot be applied to spatial research). Only a few of them (indexes developed by Mika, 2004; Gkoltsiou and Terkenli, 2008; Żemła-Siesicka, 2014) include facilities other than accommodation and food and beverage. On the other hand, one landscape load index has been developed which concerns the occurrence of mines. The above-mentioned indicators also omit the issue of the scale of the impact on landscape physiognomy occupied by tourist facilities.

\section{A characteristic of the study area}

The study area covers the geographical mesoregion of the Silesian Beskids located in Poland in the Western Carpathian Mountains (Fig. 1). The main river is the Vistula, with its springs on the slopes of Barania Góra (one of the highest peaks in the area). The major towns - Wisła, Ustroń, Szczyrk and Brenna are located in the valleys. Others - Istebna, Koniaków, Jaworzynka, and the so-called Beskid Triple Village, are situated on the top of the hills (Fig. 2).

The Silesian Beskids is a region of high landscape value due to its mountainous character, high forest cover, scenic rivers and springs, and also the specific culture of the region. Most of the area, excluding villages and towns, is protected as a landscape park. The northern and central part is dominated by natural values, with significant areas of forest also under protection as reserves and natural-landscape complexes. Valuable areas of nature, including a large reserve, also occur in the Barania Góra range in the eastern part of the Silesian Beskids. Cultural values dominate in the areas of mountain villages, especially in the southern part of the area, in Istebna, Jaworzynka and Koniaków (so-called Triple Village).

However, it is also a region struggling with the problem of progressive landscape changes caused by agriculture, urbanization, deforestation, land abandonment and tourism pressure (Sobala, Rahmonov \& Myga-Piątek, 2017). The location, in the immediate vicinity of large towns (Bielsko-Biała and Żywiec) and a few dozen kilometres from the Katowice conurbation, is important for the development of tourism. In the Silesian Beskids, tourism was already present at the beginning of the 20th century, but rapid development of services and related tourist urbanization took place in the 1960s (Mika, 2004). In Ustroń, tourism urbanization was caused by the presence of spa resources (Gonda-Soroczyńska, 2013). In the 1960s, the touristic districts started to grow, with large modern buildings of resorts and spa. The rural character of the landscape changed and the largest tourist villages were transformed into cities (Ustron was granted city rights in 1956, Wisła in 1962 and Szczyrk in 1973). 


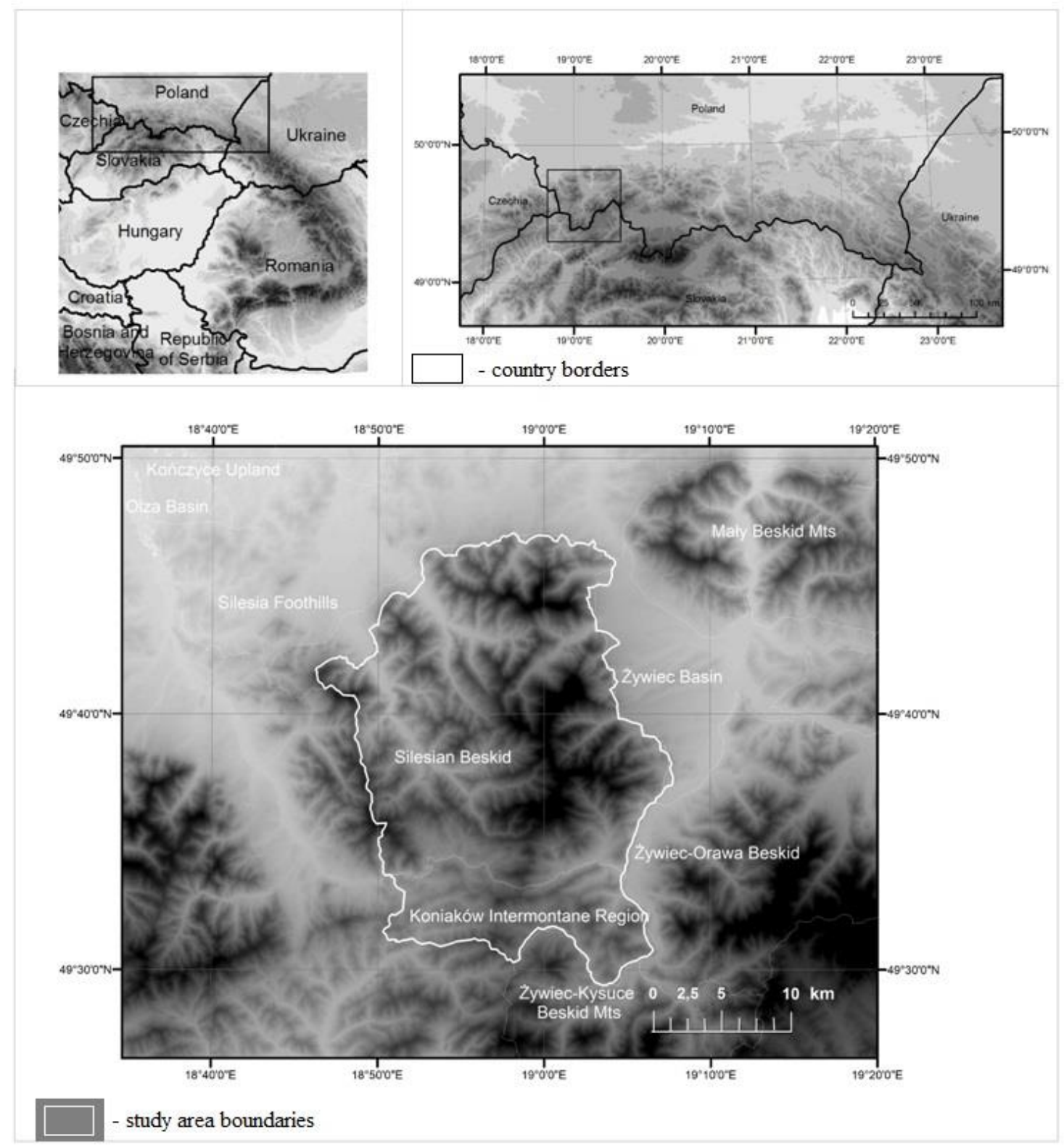

Fig 1. Location of the study area. 


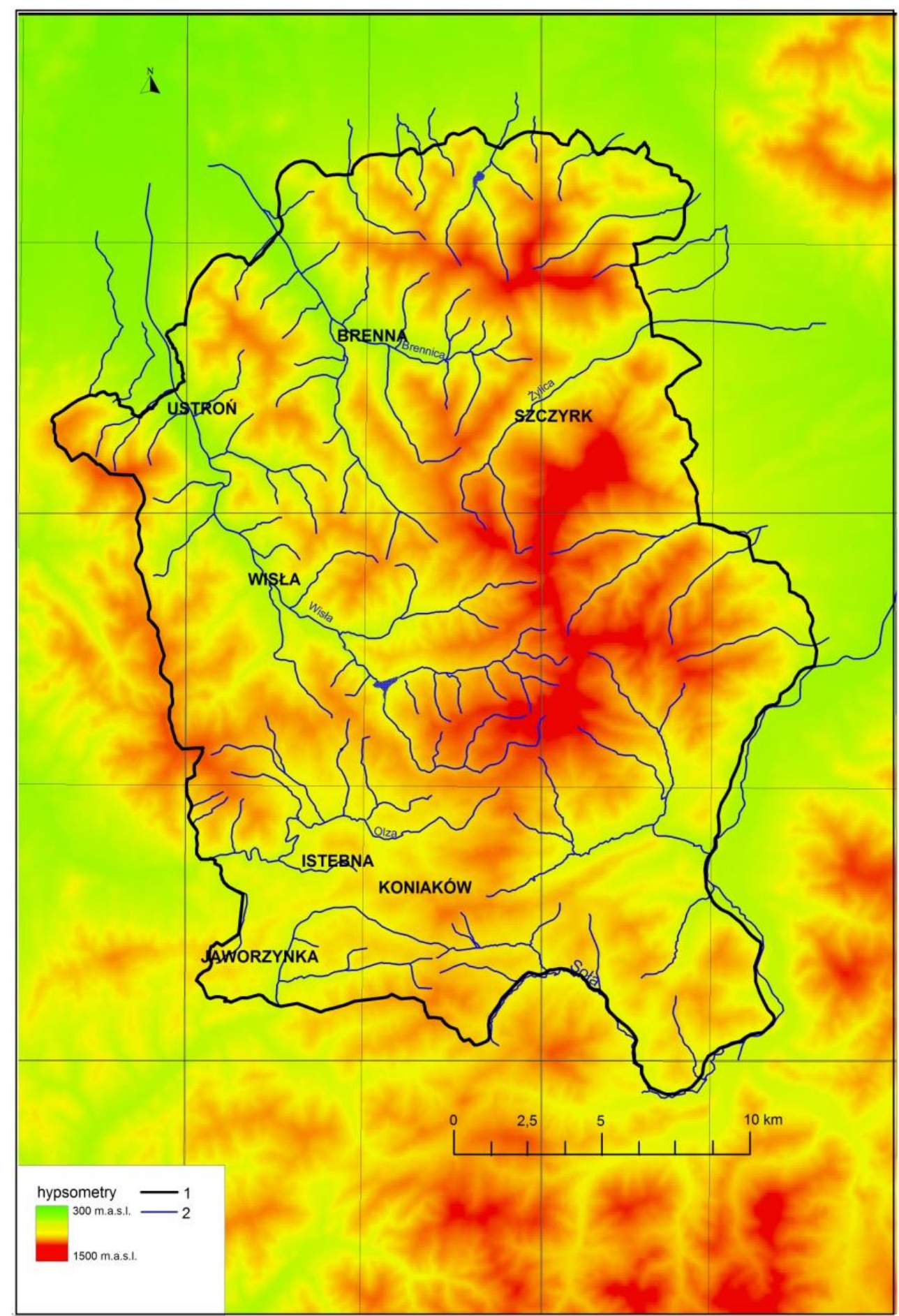

Fig 2. Main towns, villages and rivers in the Silesian Beskids.

1- study area boundaries, 2 - rivers

The physiognomy of the landscape in the Silesian Beskids has now been strongly transformed by tourist facilities (fig. 3). The large hotels and resorts are located mostly in Ustron and Wisła, while small accommodations, like guest rooms and "second homes" or recreation houses, are situated in Szczyrk, Brenna and Triple Village. Four spatial types of tourist settlement (Mika, 2004) can be distinguished in the Silesian Beskids: complexes of tourist facilities, so-called holiday districts (some districts in Wisła and Ustroń), facilities located along the main road (in Brenna and Szczyrk), solitary location - dispersed system (Triple Village) and concentrated with settlements, in the center (Ustroń, Wisła, Szczyrk). The ski resorts are very well developed, especially in Szczyrk. The pressure of other tourist facilities is also visible. For example, on the slopes of Równica, the tourist traffic was already intense in the last century, but has grown 
over the years and has resulted in the construction of many sport and leisure facilities next to hotels and restaurants (Barański, 2007, Petryszyn \& Zuzańska-Żyśko, 2009).
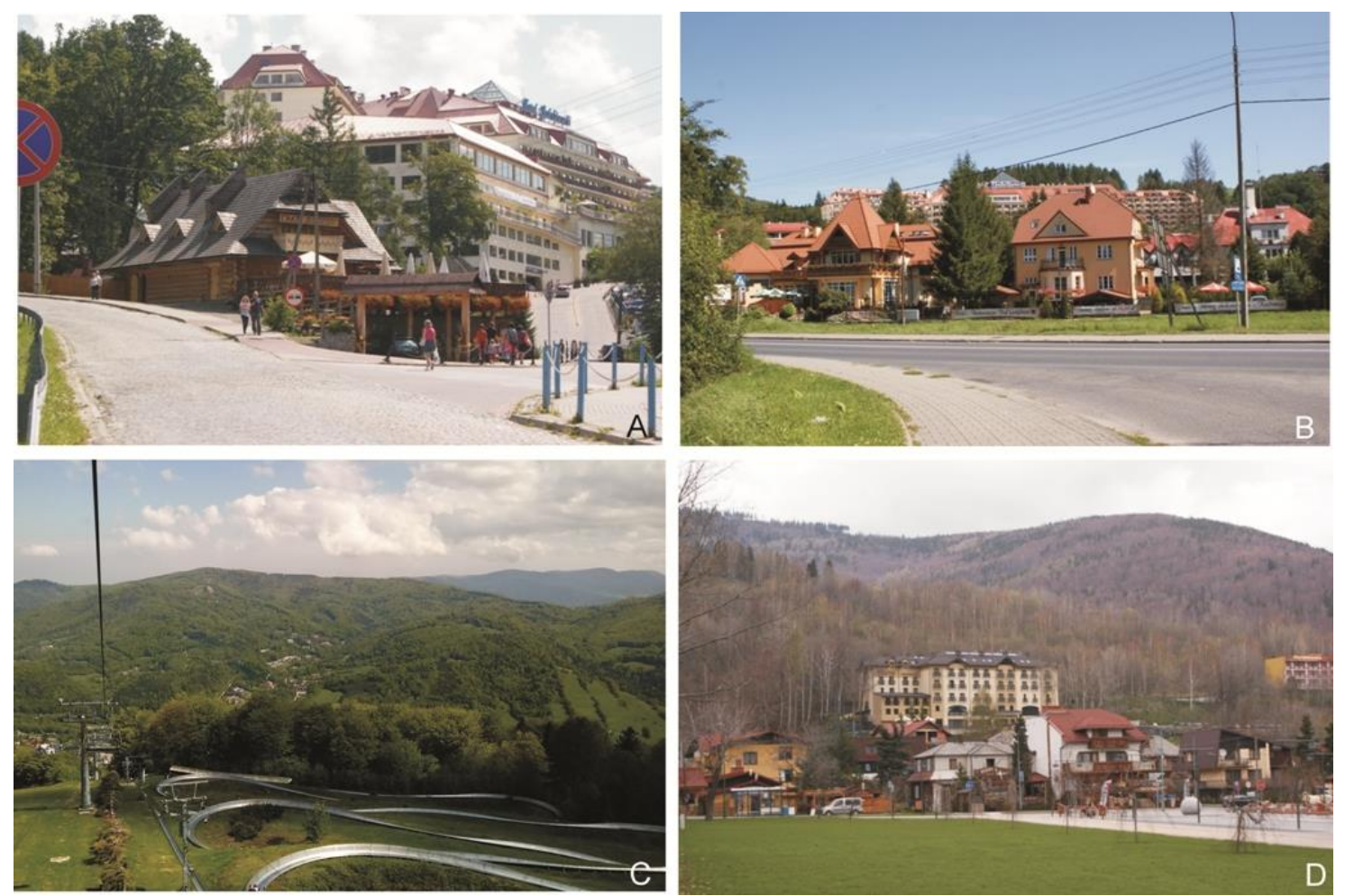

Fig 3. Landscape transformation towards tourist landscape in the Silesian Beskids. A, B - Wisła town, Gołębiewski Hotel and other accommodation and gastronomy elements, $C$ - Ustroń, toboggan, cable car and ski lift on the slope of Równica, at the back - Jaszowiec tourist district, D - Szczyrk, hotels and restaurants. (Photo by author)

\section{Methodology}

The methodology of study includes the following steps:

- delimitation of the borders of the study area,

- delimitation of spatial units,

- inventory of tourist facilities according to the developed classification,

- calculation of the landscape load with tourist infrastructure index (LLI).

\section{Delimitation of the borders of the study area}

The boundaries of the study area were determined in accordance with Kondracki's mesoregions (2002). In accordance with the latest division, the study area also comprises part of the Koniaków Intermontane mesoregion (Solon et al., 2018; Balon, Jodłowski \& Krąż, 2018). The study area covers 55040 ha.

\section{Delimitation of spatial units}

The primary spatial unit of the assessment is a river basin of the appropriate category (microbasin). River basins are understood here as individual valleys determined on the basis of water divides. The use of microbasins as a spatial unit in landscape research is not a typical approach (Żemła-Siesicka, 2017). In the case of spatial studies in mountain areas, basins form cohesive units, integrating natural processes (Kistowski, 2001) and processes related to land cover (Bertolo, 2000) and, most importantly, visible in the field. 
Using the basin criterion, spatial units were obtained based on the water divides of various categories ranging from the European watershed to category III water divides. As a result, 68 spatial units were delimitated among six microregions (described by Kondracki, 2002):

- catchments of smaller rivers in the northern part of the Beskids

(units 513.451.1 - 513.451.11),

- catchment of the Brennica (units 513.452.1 - 513.452.8),

- catchment of the Żylica (units 513.453.1 - 513.453.5),

- catchment of the Vistula (units 513.454.1 - 513.454.16),

- catchment of the Soła on the eastern slopes of Barania Góra (units 513.455.1 - 513.455.11),

- catchment of the Olza (units 513.456.1 - 513.456.10),

- $\quad$ area between Soła and its tributaries - Roztoka and Janaszka (units 513.457.1 - 513.457.7).

\section{Inventory of tourist facilities}

The infrastructure inventory was carried out on the basis of cartographic and field studies (including GIS methods). The inventory was conducted in accordance with the spatial classification of tourist infrastructure, which is based on three groups: point (in this research the term "cubature" was adopted), areal and linear elements. This kind of division based on spatial form was presented and defined (among others) by Kowalczyk and Derek (2010). Based on their definitions, the following groups were adopted in the presented study:

- cubature elements (e.g. hotels) - understood as an association of tourist facilities gathered in one building, which have tourism as their sole or predominant function,

- area elements (e.g. camp sites) - areas that perform tourist or recreational functions without buildings, as well as complexes of facilities with an area of ground floor footprint less than $50 \mathrm{~m}^{2}$ (e.g. clusters of houses or bungalows),

- linear elements (e.g. tourist trails) - including linear technical elements such as ski lifts and elements without technical equipment, such as tourist paths and trails.

The influence exerted on landscape physiognomy is varied depending on the size and spatial form of a given infrastructure element. For example, a large-size hotel has a much greater impact (both physical and aesthetic) on the landscape than a small restaurant or a ski slope, even if the area of the hotel is smaller than the area of the slope. On the other hand, not only is the size of the elements important, but also their number in a given space. As with a large-sized hotel, the landscape may be negatively affected by a high density of small-sized facilities. Another issue is the aesthetics of the objects themselves, their architectural form, the quality of materials, details, and the adaptation of style to local conditions. These aspects, however, remain in the sphere of architectural-urban scale research. They also carry a great deal of subjectivity, so have been omitted from this research.

Based on the diverse influence depending on the form and scale of the tourist infrastructure, further subdivision of the elements has been adopted. The area and cubature elements were divided into four groups on the basis of the area occupied by the individual elements: micro, small, medium and large. For linear elements, two groups were separated depending on the presence of technical equipment visible in the landscape: linear technical elements and linear elements without equipment. The division and the characteristics of the groups are presented in table 1. 
Tab 1. The division and characteristics of groups of tourist elements.

\begin{tabular}{|c|c|c|c|c|}
\hline \multicolumn{2}{|l|}{ Element } & \multirow{2}{*}{$\begin{array}{l}\text { Area in } \mathrm{m} 2 \\
50-400\end{array}$} & \multirow{2}{*}{$\begin{array}{l}\text { Example } \\
\text { small bed and breakfasts, } \\
\text { agri-tourism } \\
\text { accommodation, } \\
\text { restaurants, tourist } \\
\text { information, ski lift } \\
\text { service facilities }\end{array}$} & \multirow[b]{2}{*}{$\begin{array}{l}\text { Examples - photos taken in } \\
\text { the Silesian Beskids }\end{array}$} \\
\hline Cubature & Micro & & & \\
\hline & Small & $401-1000$ & $\begin{array}{l}\text { bed and breakfasts, } \\
\text { small hotels, restaurants, } \\
\text { mountain hostels }\end{array}$ & Mountain hostel \\
\hline & Medium & $1001-3500$ & resorts, hotels, sports halls & 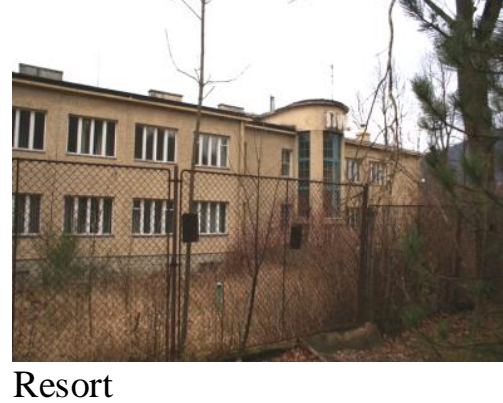 \\
\hline & Large & $\geq 3501$ & resorts, hotels & Hotel \\
\hline Area & Mikro & $\leq 1000$ & small car parks, mini golf & Mini golf course \\
\hline
\end{tabular}




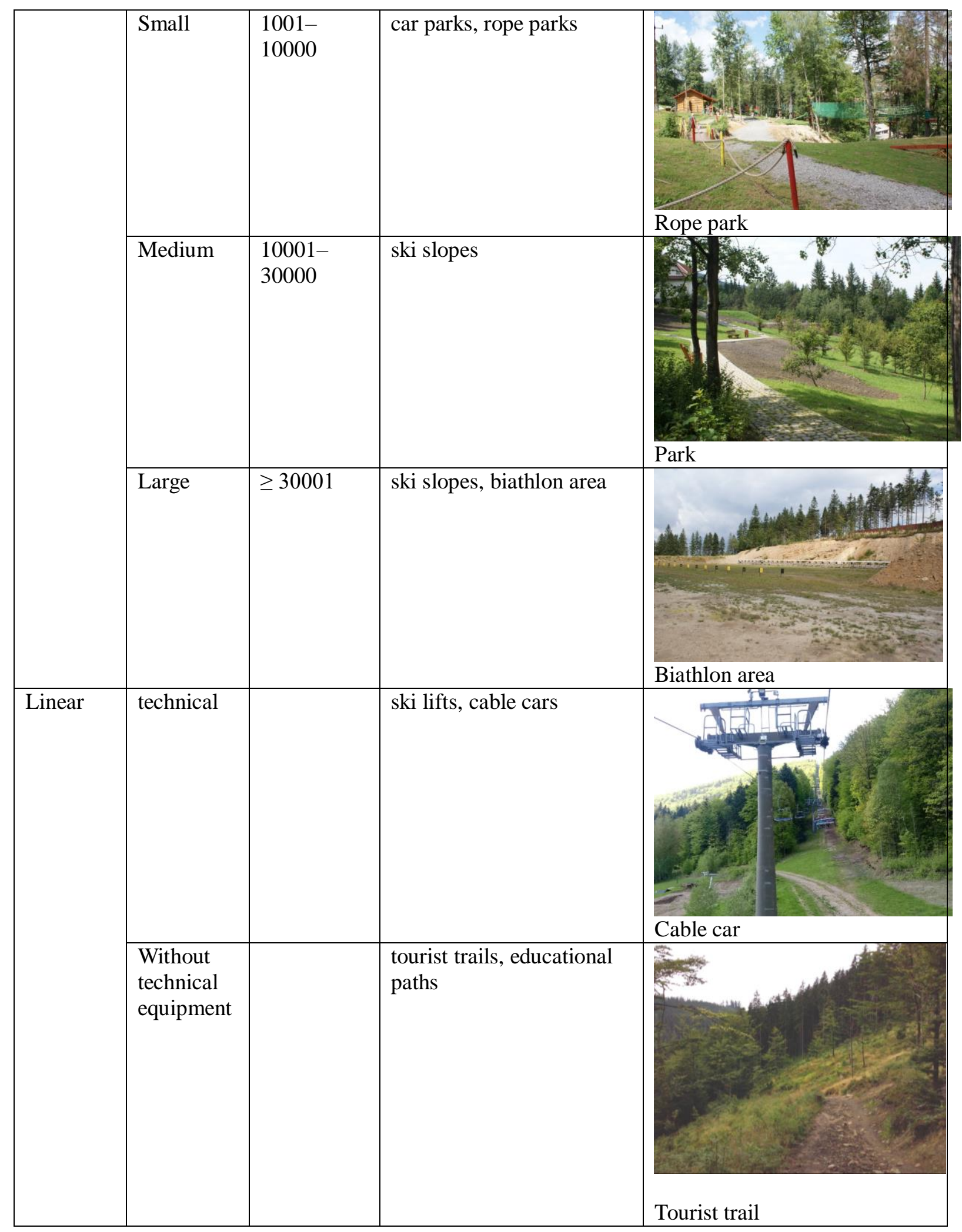

Source: own compilation, photo by author

\section{Calculation of landscape load index (LLI)}

The value of the index of the degree to which the landscape is loaded with tourist infrastructure elements is based on a calculation of the landscape saturation (occurrence of elements of a particular group per spatial unit) corrected by a qualitative coefficient $(k)$. 
The landscape saturation is presented by the following formulas:

- the saturation of the cubature elements: $\boldsymbol{S}_{c}=\boldsymbol{N}_{c} / \boldsymbol{A}_{u}$

- the saturation of the area elements: $S_{a}=N_{a} / A_{u}$

- the saturation of the linear elements: $S_{I}=L_{I} / A_{u}$

where:

$S$ - landscape saturation ( $c$ - cubature elements, $a$ - area elements, $I-$ linear elements),

$N$ - number of elements,

$L-$ length of elements $(\mathrm{km})$,

$A$ - area of the spatial unit $\left(\mathrm{km}^{2}\right)$,

To calculate the landscape load index, the following formula has been used:

\section{$L L I=\sum\left(S_{e} \times k_{e}\right)$}

where:

$S_{e}$ - landscape saturation of a particular group of elements,

$k_{e}$ - the correction coefficient, depending on the group of tourist infrastructure elements

The correction coefficient is an important element of the calculation, as introduce the qualitative value to the research. A physiognomic negative impact of facilities is differentiated, depending on the spatial character and size. The coefficient indicate the degree of influence of a particular element on the landscape. In calculating the value of the correction coefficient, only the impact of the elements on landscape physiognomy was taken into account. Due to the subjectivity of the assessment, the aesthetic values of the facilities were omitted. It was assumed that due to the geographical scale and objectivity of the assessment, the direct, physical transformation of the landscape caused by facilities (such as removal or transformation of vegetation; transformation of the relief associated with construction) and their visibility in space (domination) will be taken into account. To determine the value of the coefficient, a comparative analysis was used. The degree of intensity of influence of individual elements on physical changes and space was determined using the $0-10$ scale. The influence of a particular group of tourist infrastructure was compared to the influence of other groups. For example, it was assumed that the influence of large-size elements (i.e. the largest hotels and holiday homes, e.g. Hotel Gołębiewski) is the highest (10 points) in terms of space dominance and physical transformation (10 points), while the influence of linear elements without equipment is the lowest (2 points for physical transformation, 0 for dominance). In the case of physical changes in the landscape, each element was considered to have an influence and therefore no 0 points were allocated. The weakest impact was considered to be exerted by linear elements, the strongest by the area elements (the force of influence is directly proportional to the surface of the element). The strongest physical transformations are exerted by cubature elements, due to the significant changes in soil structure and vegetation associated with the construction of objects. In relation to the domination in space, it has been assumed that linear elements without equipment do not exert any influence due to the lack of visual influences in the landscape. The domination of surface elements in space is minor. The most dominant in space are cubature elements, depending on the size of the object, as well as linear technical elements related to the presence of traction poles of ski lifts and cable cars. The value of coefficient obtained is presented in table 2. 
Tab 2. The value of coefficient $k$.

\begin{tabular}{|c|c|c|c|c|}
\hline \multicolumn{2}{|c|}{ Tourist infrastructure element } & Physical impact & Domination & Coefficient $k$ value \\
\hline \multirow{4}{*}{ Cubature } & micro & 7 & 7 & 14 \\
\hline & small & 8 & 8 & 16 \\
\hline & medium & 9 & 9 & 18 \\
\hline & large & 10 & 10 & 20 \\
\hline \multirow{4}{*}{ Area } & micro & 3 & 1 & 4 \\
\hline & small & 4 & 2 & 6 \\
\hline & medium & 5 & 3 & 8 \\
\hline & large & 6 & 4 & 10 \\
\hline \multirow[b]{2}{*}{ Linear } & technical & 1 & 7 & 8 \\
\hline & $\begin{array}{l}\text { without technical } \\
\text { equipment }\end{array}$ & 2 & 0 & 2 \\
\hline
\end{tabular}

\section{Results}

According to the results of the research, the tourist development of the Silesian Beskids is spatially diversified (Fig. 4). The most numerous tourist infrastructure is concentrated along the river valleys of the Vistula, Brennica and Żylica. This indicator shows a strong landscape load in a large area of the Silesian Beskids. The most loaded units are located in the Vistula Valley (Wisła) and in the Żylica Valley (Szczyrk). However, the highest value of the index was recorded on the slopes of Dębowiec $(513.451 .7, \mathrm{LLI}=176.92)$ in the northern part of the area. It is a small area where tourist services have developed strongly over several years. The main reason for this is its close distance to a city - Bielsko-Biała. The area of Dębowiec is easily accessible from the city centre. In addition, there is one fundamental facility which is the oldest one there: a restaurant (before, it was a mountain chalet existing since the end of the 19th century) located on the slope which is within walking distance of the car park. In 2013, a Recreation and Skiing Centre was added which includes various kinds of facility: a chairlift, a drag lift, a ski school slope, a snow park, a climbing wall, an outdoor gym, a playground for children, an educational trail and a parking lot.

Slightly lower values are reported by units 513.454 .2 (Ustroń-Zawodzie, LLI=117.06) and 513.454.3 (Ustroń-Jaszowiec, LLI=84.16). These are areas located on the western and southern slopes of Równica where, in the 1960s and 1970s, spa and recreation infrastructure was developed (Szmitkowska, 2018). A number of characteristic buildings of considerable size (medium cubature elements) in the form of pyramids were erected in the Zawodzie district. The area was additionally equipped in later years with another hotel and (already in the 21st century) an extensive forest park with a zoo. Ustroń-Jaszowiec with its resorts (medium and small elements) is located on the less exposed slopes along Jaszowiec Stream. A significant concentration of tourist infrastructure has built up underneath the Równica Peak over several years. To the mountain chalet that has existed since 1928, car parks and gastronomy facilities were added, and, in the 21st century, a tourist-sports-entertainment complex (including a guesthouse, catering facilities, a summer toboggan run and even a cinema) and also a rope and paintball park. Additionally, in the same spatial unit, on the slopes of Palenica, there is a chairlift, T-bar ski lift and ski runs. 


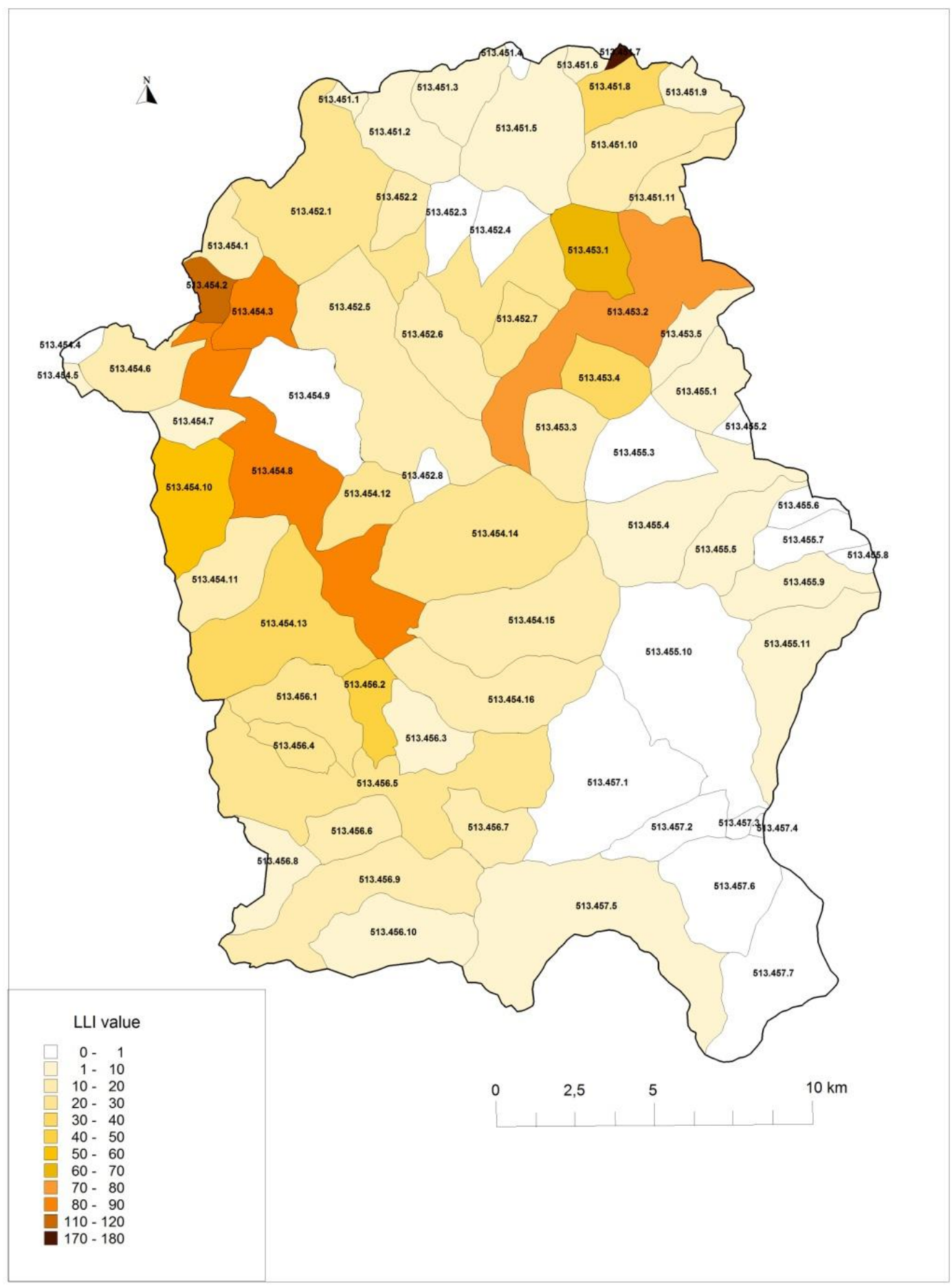

Fig 4. Value of LLI in the Silesian Beskids. The colour intensity is consistent with the intensity of the landscape load.

Another unit with an equally high ratio covers the Vistula valley and Wisła city (513.454.8, $L L I=83.93)$. This is a very broad area where elements of tourist infrastructure are gathered in three main clusters. One of them includes the slopes of Czantoria and a ski resort (with a chairlift with a large service building, ski lifts, catering facilities, and a car park). Many more facilities and equipment are located in the centre of the Vistula River with a large number of accommodation and gastronomic facilities (all sizes), but also with complementary facilities (ski lifts, ski slopes and car parks). The third cluster is the Nowa Osada district, where the infrastructure (mainly micro-cubature and micro-area) has developed around another ski resort. 


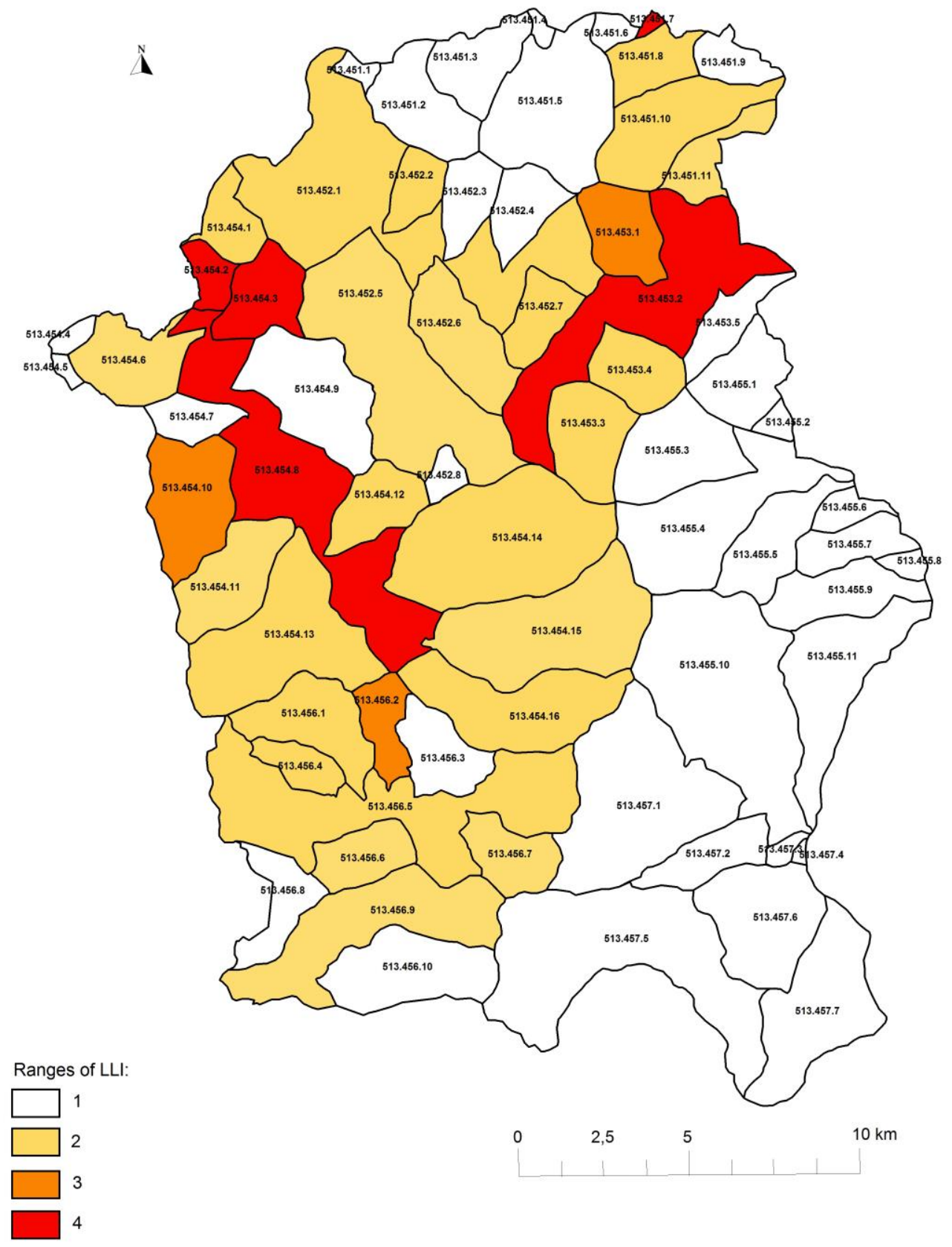

Fig 5. Ranges of LLI. 1 - unburdened areas (0-10), 2 - areas with low load ( $\geq 10-40), 3-$ areas with significant load $(\geq 40-70), 4-$ areas with high load $(\geq 70)$.

Among other units, the following ones clearly dominate: 513.453.2 (Szczyrk in the Żylica Valley, LLI=70.45) and 513.453.1. (Szczyrk-Biła, LLI=62.66) with a large accommodation and catering facilities (mainly micro and small-cubature and area elements, but with a few medium and largecubature facilities - holiday homes and a ski jump) and car parks, as well as an extensive ski resort on the Skrzyczne and numerous tourist trails.

The least loaded units are located mainly in the eastern and south-eastern parts of the area, with smaller ones on the northern slope of the Silesian Beskids and individual units in other parts. Most of these areas are largely covered by forest, with no tourist infrastructure or only with tourist trails. However, in some units, despite small areas of forest and the presence of larger or smaller settlements, no tourist development has been developed. 
On the basis of the obtained LLI values, there were separated ranges defining the degree of influence of tourist elements on the landscape (fig. 5):

- unburdened areas $(0-10)$,

- areas with low load $(\geq 10-40)$,

- areas with significant load ( $\geq 40-70)$,

- areas with high load $(\geq 70)$.

Areas classified as loaded with tourist infrastructure (significant load and high load) cover only $13 \%$ of Silesian Beskid and are situated mostly in Wisła and Szczyrk. Unburdened areas and areas with low load definitely predominate (near 88\%). Unburdened areas are especially present in eastern part of the Silesian Beskid. Areas with low landscape load covers central and western parts. Table 3 indicates the percentage share of the ranges in the Silesian Beskid.

Tab 3. Percentage share of the ranges of LLI in Silesian Beskid.

\begin{tabular}{|l|l|}
\hline Range of LLI & Percentage share \\
\hline unburdened areas & $9,04 \%$ \\
\hline areas with low load & $3,32 \%$ \\
\hline areas with significant load & $44,05 \%$ \\
\hline areas with high load & $43,58 \%$ \\
\hline
\end{tabular}

Basing on the results presented above, the following spatial factors related to the differentiation of LLI can be observed:

- character of the settlement and topography: the most loaded landscape is related to the valleys of larger rivers: Vistula, Brennica and Żylica, where the tourist infrastructure is the most numerous (Fig. 6).

- form of tourism: areas with developed mass tourism are most strongly transformed due to numerous accommodation and catering facilities, but also well-developed supporting infrastructure which also affects the landscape. These are: Ustron with its dominating healthresort tourism (large-cubature hotels); Wisła, i.e. a multifunctional resort with weekend, recreational, sport and incentive tourism (variety of types and sizes of facilities); Szczyrk ski resort (with a developed accommodation and catering facilities and infrastructure related to skiing). Less loaded is the landscape of the area focusing on agritourism and cultural tourism (Triple Village). It is characterised by numerous accommodation and gastronomic facilities, but with a smaller cubature. The supporting infrastructure is also underdeveloped here.

- communication accessibility: the best developed areas in terms of the number of infrastructure elements are those in the northern part of the Silesian Beskids, which has a better connection and is located closer to the Katowice conurbation. The importance of this factor can also be proved by the most loaded units: Dębowiec, which has a high accessibility for the inhabitants of Bielsko-Biała; Ustroń and Wisła, which are well connected by a railway and a road route (the so-called 'Wiślanka') with Katowice. 


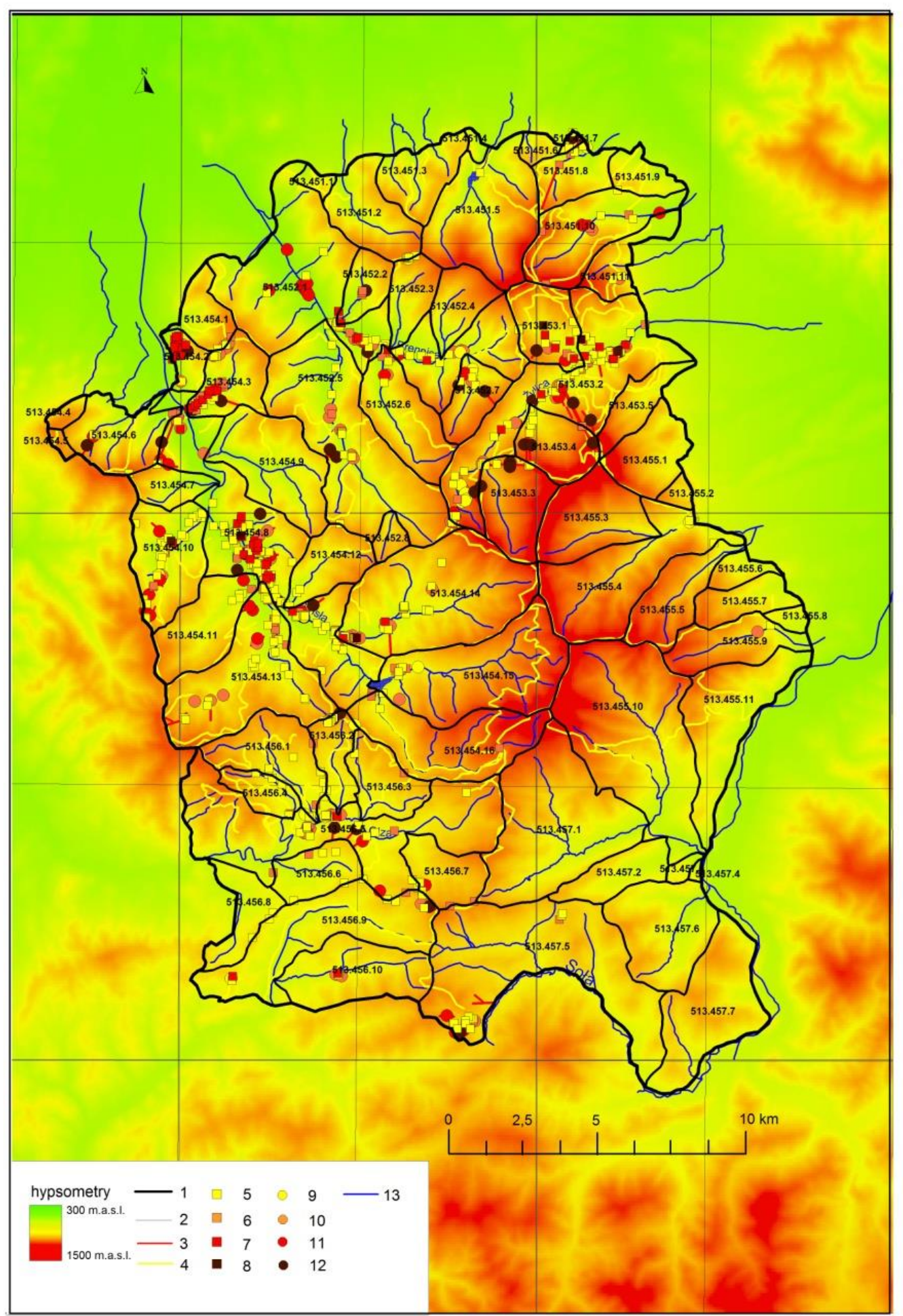

Fig 6. Spatial distribution of facilities in the Silesian Beskids on the topography backround.

1 - study area boundaries, 2 - spatial unit boundaries, 3 - linear technical elements, 4 - linear elements without equipment, 5 - micro-cubature elements, 6 -small-cubature elements, 7 - medium-cubature elements, 8 - largecubature elements, 9 - micro-area elements, 10 - small-area elements, 11 - medium-area elements, 12 - large-area elements, 13 - rivers.

- forestry: generally, the degree of development of infrastructure is related to the forest cover. In areas with high forest cover, there are usually only tourist trails with a low impact on the landscape. This is the case in the eastern part of the area, on the slopes of Barania Góra and in the northern areas of the Silesian Beskids (excluding the slopes of Dębowiec). On the other hand, there are numerous units with a low level of forestation and a total lack of touristic development (Fig. 7). 


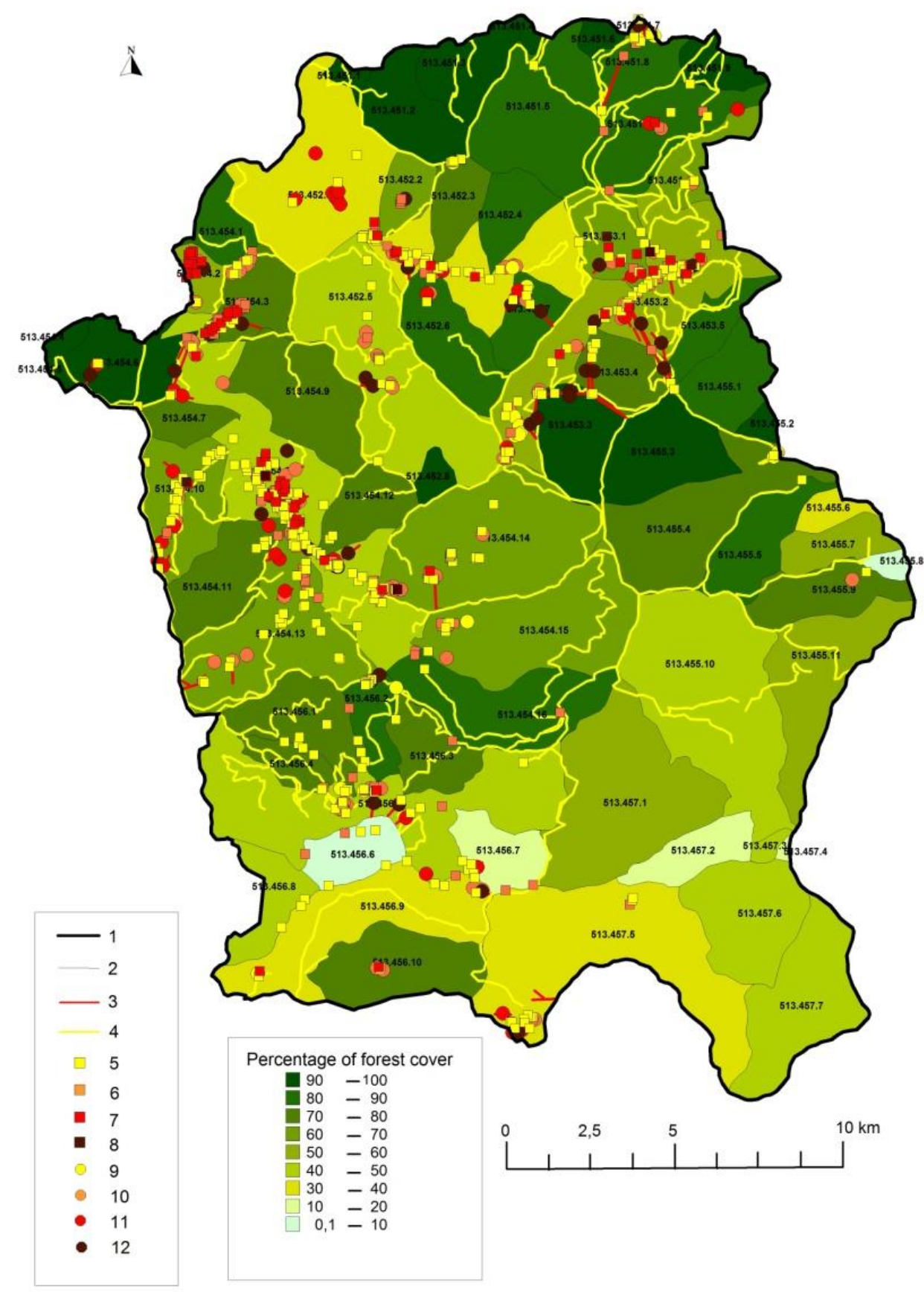

Fig 7. Spatial distribution of facilities in the Silesian Beskids on the forest cover background

1- study area boundaries, 2 - spatial unit boundaries, 3 - linear technical elements, 4 - linear elements without equipment, 5 - micro-cubature elements, 6 - small-cubature elements, 7 - medium-cubature elements, 8 - largecubature elements, 9 - micro-area elements, 10 - small-area elements, 11 - medium-area elements, 12 - large-area elements.

\section{Discussion}

The results indicate the disproportions in the load of the Silesian Beskid landscape with tourist infrastructure. The areas in the central and western parts of the Silesian Beskids are the best developed, while the south-eastern part is the least developed. Similar results, although adopting other spatial units (administrative), were obtained by Mika (2004) in the study of the impact of tourism on the natural environment (excluding the landscape aspect) of the Silesian Beskids. The areas of Szczyrk, Wisła and Ustron are the most transformed in the assessment of both the environmental impact and the impact on the landscape. Different 
results were obtained for Brenna and Bystra. In Mika's research, these are also the municipalities with a strong impact, while the LLI value is rather low for this areas. The LLI results also coincide with the values of the Defert and Charvat index calculated by Hendel (2016) for selected municipalities of the Silesian Beskids. The highest values are reported for Ustroń, followed by Szczyrk and Wisła, while Istebna and Brenna have values even several times lower. Although these are indicators of tourist traffic, their relation to the tourist infrastructure and thus to the impact on the landscape is clear. It should be noted that the river basin units adopted in the article allow a much more detailed presentation of the impact of tourism than larger administrative units. More comparable is a compilation of average LLI values for microregions, the surface of which partially coincides with the range of municipalities (Fig. 8).

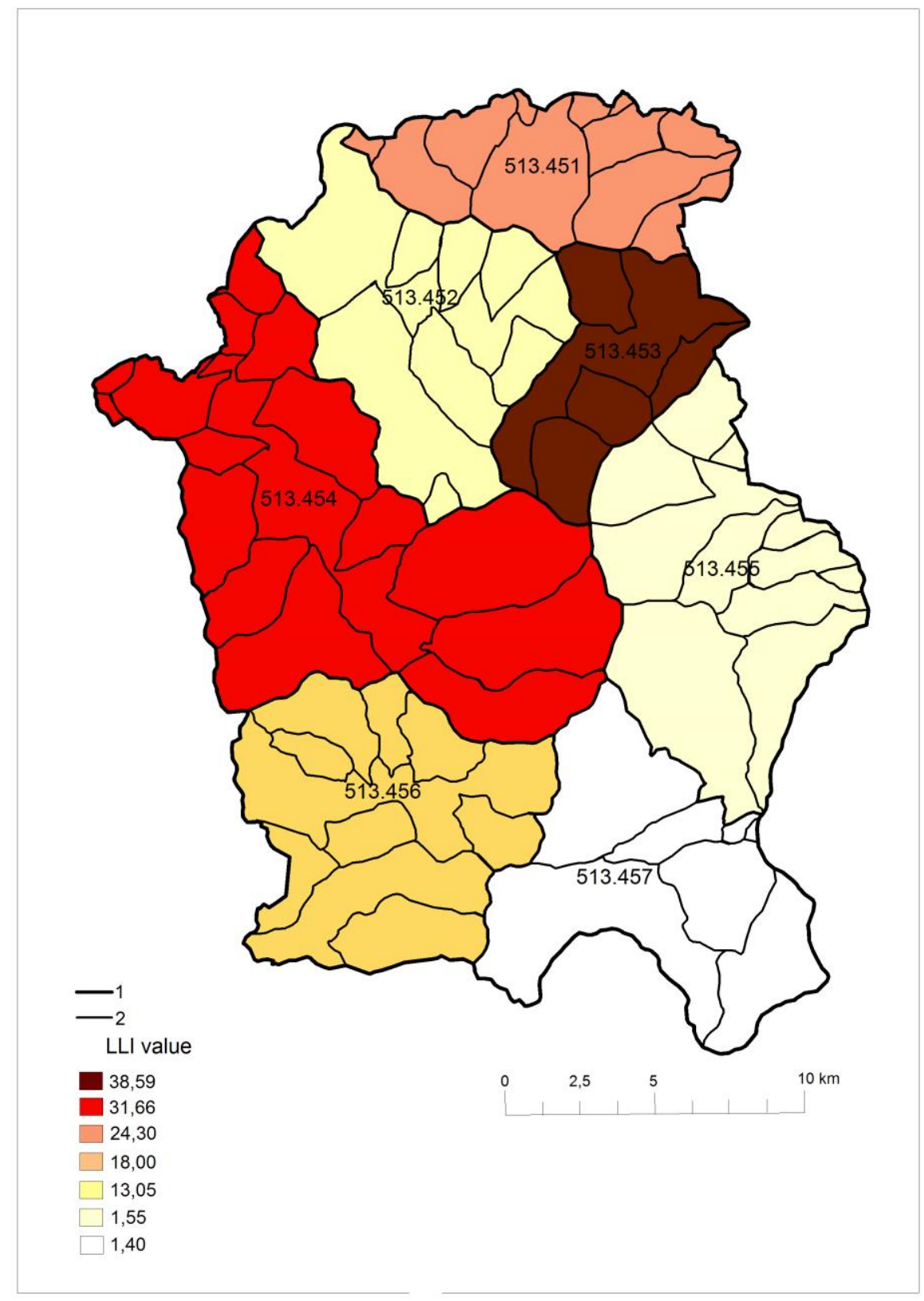

Fig 8. Average values of indicators of microregions in the Silesian Beskids. 1- study area boundaries, 2-spatial unit boundaries.

In the context of further development, an important issue is the determination of LLI limit values that would indicate a maximum acceptable landscape load, and a minimum for classifying the landscape into a tourist landscape type. The limit values of the indicators are rather arbitrarily evaluated by researchers, as in the case of an ambiguous determination of the level of the tourism function indicator (Szromek, 2012; Hendel, 2016). Applying the definition of 
a tourist landscape based on its physiognomic character, it can be assumed that the areas with the highest values of indicators of the degree of load of landscape may be qualified as tourist landscapes. These are the units taking the index value above 70: the slope of Dębowiec (with numerous elements of various character), Ustroń-Zawodzie, Ustroń-Jaszowiec (with numerous large holiday resorts), the Vistula Valley with the town of Wisła and the Żylica Valley in Szczyrk (numerous elements of various character and size, including numerous ones of considerable size).

It is also difficult to determine the maximum acceptable indicator value. The area exceeding this value should not be additionally visually burdened with the tourist infrastructure. In the case of the Silesian Beskids, such a value was undoubtedly achieved by the unit covering the slope of Dębowiec (index value is 176.92). It is advisable to significantly reduce further development in the area of units with successive index values: Ustroń-Zawodzie, 117.06, Ustroń-Jaszowiec, 84,16, Wisła town 83.93, and Szczyrk, 70.45. Setting precise limit values requires more extensive research in several areas of a similar character. However, the possibility should be noted that, even in mountain areas, the limit values can be different, and for other regions (lakeside, coastal, etc.) they will differ significantly. As in the case of natural capacity, for which limit values are adopted according to region, habitat, plant community, slope inclination, etc., local conditions must be taken into account: landform, ranges of visibility, genesis of the landscape, etc. The developed methodology of landscape load assessment can be used mainly in mountainous areas due to the adopted river basin units specific for these areas. It will also be possible to apply the method in areas of a different character (coastal, lake district) and larger scale, and in smaller areas (e.g. municipalities) if the methodology is adjusted, i.e. with other spatial units adopted.

\section{Conclusion}

In the area of the Silesian Beskids there is a strong spatial diversification of the intensity of tourist development and, consequently, the impact of tourist infrastructure on the landscape. While the landscape of the major river valleys has been largely transformed into a tourist landscape, the catchment areas of small rivers in the eastern and southern parts, despite having similar natural values, have remained untouched.

An important advantage of the indicator is the possibility of application in the forecasting and programming in the development of tourism infrastructure. Forecasting should additionally include studies of landscape transformation over the past years in order to predict further trends. Elements of such research have already been carried out for the tourist landscape of the coastal areas of Kosovo Island, covering the period 1981-2002 (Gkoltsiou \& Terkenli, 2008). Studies have demonstrated far-reaching changes for this area in, among other things, the structure of land use and settlement, and the range of visibility of the sea from the land.

The identification of areas overloaded with tourist infrastructure and areas with minimal impact on the landscape (i.e. underinvested areas) also enables a determination of the direction of further tourist development. The areas that should be excluded and areas particularly predestined for further development can be identified. The existing transformation of the landscape by tourism should be taken into account in tourist development plans and provide a basis for further guidelines to be taken into account in the planning processes of municipalities. Of course, the landscape issue is not the only one to consider while programming the development. There are a lot of other research problems to solve, including economic, social, ecological and spatial ones.

In conclusion, it should be underlined that the presented research draws one's attention to the need for a wider approach to the issue of tourist facilities and their impact on the natural environment, not limited to accommodation and catering facilities. The presented research highlights the significant impact of all kinds of tourism infrastructure on the landscape space. The perception of the tourist region, based primarily on the physiognomic aspect, largely determines if the area is attractive to tourists. The quality of the landscape is crucial not only for tourists, but also for the local population who benefit economically from tourism. Therefore, when introducing new elements of development, it is necessary to remember that economic 
profits are put on the scale along with landscape values. Adding another development element to the rural or natural landscape may bring short-term profit, but in the long run, the loss of landscape value may lead to an outflow of tourists.

\section{Academic references}

[1] Amir, S. \& Gidalizon, E. (1990). Expert-based method for the evaluation of visual absorption capacity of the landscape. Journal of Environmental Management 30(3), 251263. DOI: $10.1016 / 0301-4797(90) 90005-\mathrm{H}$.

[2] Anderson, L. R., Bennetts, R., Chandler, G., Galliano, S., Holcomb, D. \& Neville, B. (1976). Visual Absorption Capability for Forest Landscapes USDA Forest Service. Yreka, CA: Klamath National Forest.

[3] Andrejczuk, W. (2010). Krajobraz a turystyka: aspekt konceptualny. In: Prace Komisji Krajobrazu Kulturowego 14 (pp. 15-25). Sosnowiec: PTG.

[4] Atik, M., Altan, T. \& Artar, M. (2010). Land Use Changes in Relation to Coastal Tourism Developments in Turkish Mediterranean. Polish Journal of Environmental Studies, 19(1), 21-33.

[5] Balon, J., Jodłowski, M. \& Krąż, P. (2018). Mikroregiony fizycznogeograficzne Tatr Zachodnich. Prace Geograficzne, 91( 2), 143-170.

[6] Baranowska-Janota, M. \& Kozłowski, J. (1984). Krańcowe progi przyrodnicze w rozwoju turystyki Warszawa: Instytut Kształtowania Środowiska.

[7] Barański, M. (2007). Beskid Śląski - przewodnik. Piastów: Oficyna Wydawnicza Rewasz.

[8] Baretje, R. \& Defert, P. (1972). Aspects economiques du tourisme. Paris: Editions BergerLavrault.

[9] Bertolo, F. (2000). Catchment delineation and characterisation. Catchment Characterisation and Modelling. EuroLandscape Project. Space Applications Institute. Ispra: Joint Research Centre. Available from: http://agrienv.jrc.it/publications/pdfs/CatchRev.pdf. Accessed: 10 May 2018.

[10] Bodoque, J. M., Ballesteros-Cánovas, J. A., Rubiales, J. M., Perucha, M. A., NadalRomero, E. \& Stoffel, M. (2017). Quantifying Soil Erosion from Hiking Trail in a Protected Natural Area in the Spanish Pyrenees. Land Degradation and Development, 28, 22552267. DOI: 10.1002/ldr.2755.

[11] Boori, M. S., Voženílek, V. \& Choudhary, K. (2015). Land use/cover disturbance due to tourism in Jeseníky Mountain, Czech Republic: A remote sensing and GIS based approach. The Egyptian Journal of Remote Sensing and Space Science, 18(1), 17-26. DOI: 10.1016/j.ejrs.2014.12.002.

[12] Briassoulis, H. (2002). Sustainable tourism and the question of the commons. Annals of Tourism Research 29(4), 1065-1085. DOI: 10.1016/S0160-7383(02)00021-X.

[13] Buckley, R., Pannell, J. (1990). Environmental impacts of tourism and recreation in national parks and conservation reserves. Journal of Tourism Studies, 1(1), 24-32. DOI: 10.1007/978-3-642-76502-5_13.

[14] Buckley, R. Ch. (2003). Ecological Indicators of Tourist Impacts in Parks. Journal of Ecotourism, 2(1), 54-66. DOI: 10.1080/14724040308668133.

[15] Buckley, R. Ch., ed. (2004). Environmental Impacts of Ecotourism. Wallingford: CABI. DOI: 10.1079/9780851998107.0000.

[16] Butler, R. W. (1996). The concept of carrying capacity for tourism destinations: Dead or merely buried? Progress in Tourism and Hospitality Research 2(3-4), 283-293. DOI: $10.1002 /$ pth.6070020309. 
[17] Csüllög, G., Horváth. G., Tamás, L., Szabó, M. \& Munkácsy, B. (2017). Quantitative Assessment of Landscape Load Caused by Mining Activity. European Countryside, 9(2), 230-244. DOI: 10.1515/euco-2017-0014.

[18] Čuka, P., Gregorová, B. (2011). Cechy i kierunki urbanizacji turystycznej na Słowacji przykład stacji narciarskiej Donovaly. Prace Geograficzne 125, 9-18.

[19] Dietvorst, A. (1996). Tourist landscapes. Accelerating transformations. In Scraton, S., ed., Leisure, Time and Space, Meanings and Values in People's Lives (pp. 13-24), Brighton: LSA Publication.

[20] Durydiwka, M. (2014). Between tradition and modernity: Selected aspects of cultural changes under the influence of tourism (on the examples of tourism reception regions). Turystyka Kulturowa 10, 105-122.

[21] Gkoltsiou, K. \& Terkenli, T. S. (2008). Landscape indicators: A promising tool for analysis of tourist landscape structure. Studing, Modeling and Sense Makingn of Planet earth [unpublished paper]. Mytilene: University of the Aegean.

[22] Gkoltsiou, A. \& Terkenli, S. (2012). An interdisciplinary analysis of tourist landscape structure. Tourismos: an International Multidisciplinary Journal of Tourism 7(2), 145-164.

[23] Gkoltsiou, A. Terkenli, T. \& Koukoulas, S. (2013). Landscape indicators for the evaluation of tourist landscape structure. International Journal of Sustainable Development \& World Ecology 20(5), 461-475. DOI: 10.1080/13504509.2013.827594.

[24] Giedych, R. (2016). Ocena wizualnego wpływu przedsięwzięć na krajobraz - nowe wyzwanie dla ocen środowiskowych. Przestrzeń $i$ Forma, 26, 105-114. DOI: 10.21005/pif.2016.26.C-03.

[25] Gonda-Soroczyńska, E. (2013). Nietypowe połączenie funkcji uzdrowiskowej z funkcją przemysłową na przykładzie uzdrowiska Ustroń. Infrastruktura i ekologia terenów wiejskich, 3(2), 31-46.

[26] Gormsen, E. (1997). The impact of tourism on coastal areas. GeoJournal. 42(39), 39-54. DOI: $10.1023 / A: 1006840622450$.

[27] Gunn, C. A. (1979). Landscape assessment for tourism. In Elsner, G. H. \& Smardon, R. C., eds., Proceedings of our national landscape: a conference on applied techniques for analysis and management of the visual resource (pp. 409-414). Washington: United States Department of Agriculture.

[28] Hendel, M. (2016). Przydatność wskaźników funkcji turystycznej w ocenie rozwoju turystycznego obszaru na przykładzie gminy Ustroń. Zeszyty Naukowe Politechniki Śląskiej, Seria: Organizacja i Zarządzanie, 87, 157-170.

[29] Hernández, J., García, L. \& Ayuga, F. (2004). Integration Methodologies for Visual Impact Assessment of Rural Buildings by Geographic Information Systems. Biosystems Engineering 88(2), 255-263. DOI: 10.1016/j.biosystemseng.2004.02.008.

[30] Jansen-Verbeke, M. \& McKercher, B. (2013). Reflections on the Myth of Tourism Preserving "Traditional" Agricultural Landscapes. Journal of Resources and Ecology, 4(3). 242-249. DOI: 10.5814/j.issn.1674-764x.2013.03.007.

[31] Kapera, I. (2010). Turystyka w planach zagospodarowania przestrzennego gmin i województw w Polsce. Ekonomiczne Problemy Usług 52, 485-496.

[32] Kistowski, M. (2001). Wybrane problemy metodologiczne i terminologiczne opracowań ekofizjograficznych. Problemy Ocen Środowiskowych, 3(14), 32-39.

[33] Kondracki, J. (2002). Geografia regionalna Polski. Warszawa: Wydawnictwo Naukowe PWN.

[34] Kostopoulou, S. \& Kyritsis, J. (2006). A Tourism Carrying Capacity Indicator for Protected Areas. Anatolia, 17(1), 5-24. DOI: 10.1080/13032917.2006.9687024. 
[35] Krajewski, P. \& Mastalska-Cetera, B. (2014). Zastosowanie oceny pojemności krajobrazu w planowaniu przestrzennym na obszarach chronionych na przykładzie miejscowości Sulistrowice w gminie Sobótka. Problemy Ekologii Krajobrazu, 37, 147-164.

[36] Kowalczyk, A. \& Derek, M. (2010). Zagospodarowanie turystyczne. Warszawa: Wydawnictwo Naukowe PWN.

[37] Lozato-Giotart, J. P. (1993). Géographie du tourisme. Paris: Masson.

[38] Manning, R. E. (2002). How Much is Too Much? Carrying Capacity of National Parks and Protected Areas. In Arnberger, A., Brandenburg, C. \& Muhar, A., eds., Monitoring and Management of Visitor Flows in Recreational and Protected Areas (306-313). Wien: Universität für Bodenkultur.

[39] Matczak, A. (2015). Ewolucja turystyki na obszarach wiejskich. Studia Komitetu Przestrzennego Zagospodarowania Kraju PAN 162, 63-82.

[40] Meyer, B. (2011). Turystyka a ład przestrzenny wzajemne relacje. Turyzm 21(1-2), 25-32.

[41] Mika, M. (2004). Turystyka a przemiany środowiska przyrodniczego Beskidu Śląskiego. Kraków: Jagellonian University.

[42] Mika, M. \& Faracik, R. (2008). Second homes as a factor of the transformation of ruralareas in the Polish Carpathians. Folia geographica 12, 245-255.

[43] Myga-Piątek, U. (2006). Krajobraz kulturowy jako walor i produkt turystyczny - problemy oceny i ochrony. Problemy Ekologii Krajobrazu, 28, 201-212.

[44] Myga-Piątek, U. \& Jankowski, G. (2009). Wpływ turystyki na środowisko przyrodnicze I krajobraz kulturowy - analiza wybranych przykładów obszarów górskich. Problemy Ekologii Krajobrazu, 25, 27-38.

[45] Myga-Piątek, U. (2012). Krajobrazy sakralne i religijne. Próba umiejscowienia w typologii krajobrazów kulturowych. Prace Komisji Krajobrazu Kulturowego 17, 13-23.

[46] Myga-Piątek, U. (2016). Krajobraz jako autentyk, makieta, hybryda. Rozważania o roli krajobrazu we współczesnej turystyce. Turystyka Kulturowa, 1, 47-63.

[47] Nita, J., Myga-Piątek, U. \& Absalon, D. (2015). Assessment of the Exposure of TourismRelated Landscape Values of the Silesian Beskids Based on Computer Visualization. Landscape Analysis and Planning. In Luc, M., Somorowska, U., Szmańda, J., eds., Landscape Analysis and Planning (pp. 45-58). Cham: Springer. DOI: 10.1007/978-3319-13527-4_3.

[48] Ozimek, P., Tarko, J. \& Łabędź, P. (2010). Cyfrowe modele analizy krajobrazu bazujące na cyfrowych modelach terenu systemów informacji przestrzennej. Prace Komisji Krajobrazu Kulturowego PTG, 14, 342-351.

[49] Petryszyn, J. \& Zuzańska-Żyśko, E. (2009). Etapy rozwoju gospodarczego i przestrzennego Ustronia. Prace Naukowe Uniwersytetu Śląskiego nr 2736, s. 127-145.

[50] Prince, S. (2019). Dwelling and tourism: embracing the nonrepresentational in the tourist landscape. Landscape Research, 44(6), 731-742, DOI: 10.1080/01426397.2018.1518520.

[51] Richling, A. (2010). O krajobrazie raz jeszcze. Czy istnieją krajobrazy rekreacyjne? Problemy Ekologii Krajobrazu 27, 341-344.

[52] Rixen, Ch. \& Rolando, A. (2013). The Impacts of Skiing and Related Winter Recreational Activities on Mountain Environments, Sharjah: Bentham Books.

[53] Roberts, L., Hall, D., Morag, M. (2017). New Directions in Rural Tourism. London: Routledge.

[54] Rygiel, P. (2007). Odporność wizualna krajobrazu - zastosowanie w planowaniu przestrzennym. Czasopismo Techniczne. Architektura, 10(5-A), 257-258.

[55] Sanagustin Fons, M. V., Mosene Fierro, J. A. \& Gomez y Patino, M. (2011). Rural tourism: 

A
sustainable alternative.
Applied
Energy
$88(2)$,
$551-557$.

DOI: 10.1016/j.apenergy.2010.08.031.

[56] Sayan, M. S. \& Atik, M. (2011). Recreation Carrying Capacity Estimates for Protected Areas: A Study of Termessos National Park. Ekoloji 20(78), 66-74. DOI: $10.5053 /$ ekoloji.2011.7811.

[57] Skowronek, E., Tucki, A. \& Huijbens, E. (2018). What is the tourist landscape? Aspects and features of the concept. Acta Geographica Slovenica, 58(2), 73-85.

[58] Sobala, M., Rahmonov, O. \& Myga-Piątek, U. (2017). Historical and contemporary forest ecosystem changes in the Beskid Mountains (southern Poland) between 1848 and 2014. iForest Biogeosciences and Forestry, 10, 939-947. DOI: 10.3832/ifor2418-010.

[59] Solon, J., Chmielewski, T. J., Myga-Piątek, U. \& Kistowski, M. (2015). Identyfikacja i ocena krajobrazów Polski - etapy i metody postępowania w toku audytu krajobrazowego w województwach. Problemy Ekologii Krajobrazu 40, 55-76.

[60] Solon, J., Borzyszkowski, J., Bidłasik, M., Richling, A., Badora, K., Balon, J., BrzezińskaWójcik, T., Chabudziński, Ł., Dobrowolski, R., Grzegorczyk, I., Jodłowski, M., Kistowski, M., Kot, R., Krąż, P., Lechnio, P., Macias, A., Majchrowska, A., Malinowska, E., Migoń, P., Myga-Piątek, U., Nita, J., Papińska, E., Rodzik, J., Strzyż, M., Terpiłowski, S. \& Ziaja, W. (2018). Physico-geographical mesoregions of Poland: Verification and adjustment of boundaries on the basis of contemporary spatial data. Geographia Polonica 91(2), 143170. DOI: 10.7163/GPol.0115.

[61] Szmitkowska, A. (2018). Architektura pracowniczych ośrodków wczasowych w Polsce. Zarys problematyki. Architectus 3(55), 83-100, DOI: 10.5277/arc180307.

[62] Szromek, A. (2012). Wskaźniki funkcji turystycznej. Koncepcja wskaźnika funkcji turystycznej i uzdrowiskowej. Gliwice: Wydawnictwo Politechniki Śląskiej.

[63] Tesler, M. \& Clark, T. A. (2019). The impact of bouldering on rock-associated vegetation. Biological Conservation, 204(B), 426-433. DOI: 10.1016/j.biocon.2016.10.004.

[64] Terkenli, T. S. (2002). Landscapes of tourism: towards a global cultural economy of space? Tourism Geographies 4(3), 227-254. DOI: 10.1080/14616680210147409.

[65] Włodarczyk, B. (2011). The tourism landscape and tourist space of the city. Folia Turistica 25(1), 265-282.

[66] Yu, Y., Byun, W. H., Lee, T. J. (2014). Critical issues of globalisation in the international hotel industry. Current Issues in Tourism 17(2), 114-118. DOI: 10.1080/13683500.2012.761 678.

[67] Żemła-Siesicka, A. (2014). Analiza przestrzenna elementów infrastruktury turystycznej Beskidu Śląskiego. Prace Komisji Krajobrazu Kulturowego 25, 47-56.

[68] Żemła-Siesicka, A. (2017). Delimitacja pól podstawowych mezoregionu Beskid Śląski na potrzeby badań przestrzennych infrastruktury turystycznej. (Delimitation of basic fields of mezoregion of silesian beskid to the purpose of spatial researches of tourist infrastructure). Prace Komisji Krajobrazu Kulturowego PTG, 37, 127-140. 